\begin{tabular}{ll} 
Bentham open & The Open Dentistry Journal \\
CrossMark & Content list available at: www.benthamopen.com/TODENTJ/ \\
DOI: $10.2174 / 1874210601812011059,2018,12,1059-1068$ & $\substack{\text { The } \\
\text { Open Dentisty } \\
\text { lournal }}$ \\
\hline
\end{tabular}

CASE REPORT

\title{
Malignant Transformation of Ossifying Fibroma into Parosteal Osteosarcoma with High-grade Component: Presentation of an Unusual Case and Review of the Literature
}

\author{
${\text { Jahan } \text { Abtahi }^{1,2, *} \text { and Aida Ajan }}^{1}$ \\ ${ }^{I}$ Department of Oral and Maxillofacial Surgery, Linköping University Hospital, Linköping, Sweden \\ ${ }^{2}$ Department of Otolaryngology, Head and Neck Oncology, Linköping University Hospital, Linköping, Sweden
}

Received: July 27, 2018

Revised: October 16, 2018

Accepted: November 14, 2018

\section{Abstract:}

\section{Background:}

Parosteal Osteosarcoma of the Jaw (POSJ) is a rare entity that is associated with a high survival rate. Several case reports and case series of POSJ have been published in the literature, but few authors have described development of this tumor by possible transformation from a fibro-osseous neoplasm.

\section{Objective:}

We present a rare occurrence of parosteal osteosarcoma with involvement of the posterior maxilla, orbit floor, and infra-temporal fossa in a 20-year-old man. Furthermore, we performed a literature review regarding clinical, radiological, and histological features; treatment strategies; and etiology/pathophysiology.

\section{Methods:}

A PubMed search yielded a total of 74 articles and the articles were sorted according to their corresponding key area of focus.

\section{Results:}

This was a case of POSJ with high-grade component in the maxillofacial region of a 20-year old male. Co-expression of MDM2 and CDK4 was confirmed. At 2.5-year follow-up, the patient had died. The literature review revealed 18 articles including 20 cases of POSJ. Four cases represent the possible development of this tumor by transformation from a fibro-osseous neoplasm: Two cases of fibrous dysplasia, one case of cemento-ossifying fibroma, and the case of Ossifying Fibroma (OF) in the present study.

\section{Conclusion:}

In conclusion, we found an unusual case of POSJ of the midface in a patient with a previous diagnosis of OF in the same region. To our knowledge, there have been no previous reports of development of POSJ in OF. Furthermore, this is the first described case of high-grade surface osteosarcoma in the craniofacial region.

Keywords: Facial bone, Jaw, Malignant tumor, Neoplasm, Osteosarcoma, Parosteal.

\section{INTRODUCTION}

Osteosarcoma (OS) is the most common primary malignancy of bone tissue, and the sites most affected are the long

\footnotetext{
" Address Correspondence to this author at Department of Oral and Maxillofacial Surgery, Linköping University Hospital, SE-581 85 Linköping, Sweden/ Department of Otolaryngology, Head and Neck Oncology, Linköping University Hospital, SE-581 85 Linköping, Sweden; Tel: +46 (0)70 75669 97; E-mails: jahan.linkoping@gmail.com, jahan.abtahi@regionostergotland.se
} 
bones of the extremities [1]. Head and neck osteosarcoma (HNOS) accounts for approximately $10 \%$ of all OS and less than $1 \%$ of all head and neck cancers $[1,2]$. In the craniofacial region, the sites most affected are mandible and maxilla $(85 \%)$ with a peak incidence in the fourth decade of life [3, 4]. The presenting symptoms are paresthesia over the affected area, swelling, and facial pain [2, 5]. The duration of symptoms and tumor size vary at diagnosis. In the literature, a median duration of symptoms of 4 months (range 1-46 months) and a median size of 5.5 cm (range 1.2-15 $\mathrm{cm})$ have been described [6].

Osteosarcomas are divided into central osteosarcomas, which are usually more aggressive, and surface osteosarcomas [7]. Surface osteosarcomas are further classified into three subtypes: parosteal, periosteal, and highgrade surface osteosarcomas. Parosteal and periosteal osteosarcomas are described as low-grade tumors, usually with more benign clinical characteristics. Most of the jaw bone osteosarcomas are intramedullary tumors with extraskeletal extension. Surface osteosarcomas account for about 3-6\% of all osteosarcomas, and arise from periosseous tissues adjacent to the cortex [8]. Low-grade osteosarcomas may be mistaken for fibro-osseous neoplasms [9], and in the literature there are several reports of osseous lesions behaving in an aggressive fashion [10 - 14].

The diagnosis of parosteal osteosarcoma is based on radiological and histological findings. Although this tumor has some radiological characteristics, the histological evidence is important for final diagnosis and differentiation of lowgrade osteosarcoma from benign histological mimics $[15,16]$. Furthermore, Salinas-Souza et al. demonstrated MDM2 amplifications in $79 \%$ of patients with POSJ as compared to $12 \%$ in patients with conventional osteosarcoma [15]. The importance of positive immunostaining for CDK4 and/or MDM2 in detection of low-grade osteosarcoma has also been highlighted by others [16].

Moreover, malignant transformation from benign lesions into osteosarcomas in the craniofacial region is known to occur. Ossifying Fibromas (OFs) are benign fibro-osseous pathologies of non-odontogenic lineage, characterized by the replacement of normal bone structure with abnormal fibro-osseous connective tissue. These tumors show areas of radiolucency and radiopacity as they progress [17 - 19]. Despite being benign in their biological behavior, these tumors can become large, especially in the posterior maxilla, and displace dentition if they are not diagnosed in a timely manner and treated appropriately [20].

Malignant transformation of fibro-osseous lesions into osteosarcoma in the craniofacial area is uncommon. Only a few cases have been reported in the literature [21 - 23]. However, to our knowledge malignant transformation of OF has not previously been reported in the literature. Here we present the first case of POSJ with high-grade component by possible transformation from OF. In addition, we performed a literature review regarding POSJ and malignant transformation of $\mathrm{OF}$.

\section{MATERIALS AND METHODS}

A report of one case of parosteal osteosarcoma of the maxilla is presented. Approval was given by the relevant authorities to review the patient's medical and radiological records. Patient consent was also received. The Department of Pathology at the patient's country of birth confirmed the diagnosis ossifying fibroma, although no histopathological material had been kept.

We performed a PubMed search of the literature in English up to and including December 2017, using key areas of focus. We included case reports, case series, and literature reviews. Animal and experimental studies were excluded. The search strategy included the following key words: "surface/parosteal/juxtacortical osteosarcoma of the jaw"; "surface/parosteal/juxtacortical osteosarcoma of the mandible"; "surface/parosteal/juxtacortical osteosarcoma of the maxilla"; "surface/parosteal/juxtacortical osteosarcoma of the head and neck"; "high-grade/surface/parosteal/ juxtacortical osteosarcoma"; and "malignant transformation of fibro-osseous lesion".

The search results were initially evaluated based on the availability of a PubMed abstract and the full text of each article. The titles and abstracts were then evaluated for determination of relevance and to avoid any duplication. The remaining articles were read in full text. Data were analyzed with regard to age, gender, location of tumor, patient symptoms, presence of metastasis, cancer stage, treatment type, and follow-up time. Clinical, radiological, and histological findings; treatment strategies; and etiology/pathophysiology were also considered.

\section{CASE REPORT}

In 2016, a 20-year-old male patient was referred to the Department of Otorhinolaryngology (ENT), Head and Neck Surgery at Linköping University Hospital, Sweden. The patient's complaint was a rapidly growing swelling in the right 
side of his face. He had been noticing the swelling over a period of 6 months and the symptoms were associated with pain and a feeling of tension from the lateral orbit. In 2014, he had undergone surgical removal of part of the right posterior maxilla at a Department of Oral and Maxillofacial Surgery abroad. A histological record from the Department of Pathology in the patient's country of birth confirmed the diagnosis ossifying fibroma. There had been no signs of malignancy.

Extraoral examination at our department revealed two expansible swellings, one at the lateral border of the right orbital rim $(2 \times 2 \mathrm{~cm})$ and the other at the right cheek $(4 \times 4 \mathrm{~cm})$. Other findings were paresthesia in the area involved and tenderness on palpation. No regional lymph node involvement was found. Intraorally, swelling involved the right maxillary tuber with palatal expansion. Adjacent teeth were vital with no mobility, tenderness, or displacement. No other relevant family or medical history could be found. Hematological and biochemical test results were within normal range. A biopsy was performed at the right side of the posterior maxilla.

CT-scan revealed an expansile mass measuring $40 \times 50 \mathrm{~mm}$ at the right side of the infra-temporal fossa, pterygopalatine fossa, and masticatory space (Figs. 1A \& B). CT-scan showed a relatively intact cortex with exophytic growth of tumor mass (Fig. 1B). Magnetic Resonance Imaging (MRI) showed a multi-lobulated mass that involved the maxillary sinus, and extending superiorly onto the lateral orbital rim. Posterior extension was seen up to the pterygoid plates and medial extension to the lateral wall of the posterior maxilla (Figs. 1C \& D). CT-scan of the chest was performed and metastasis was ruled out.

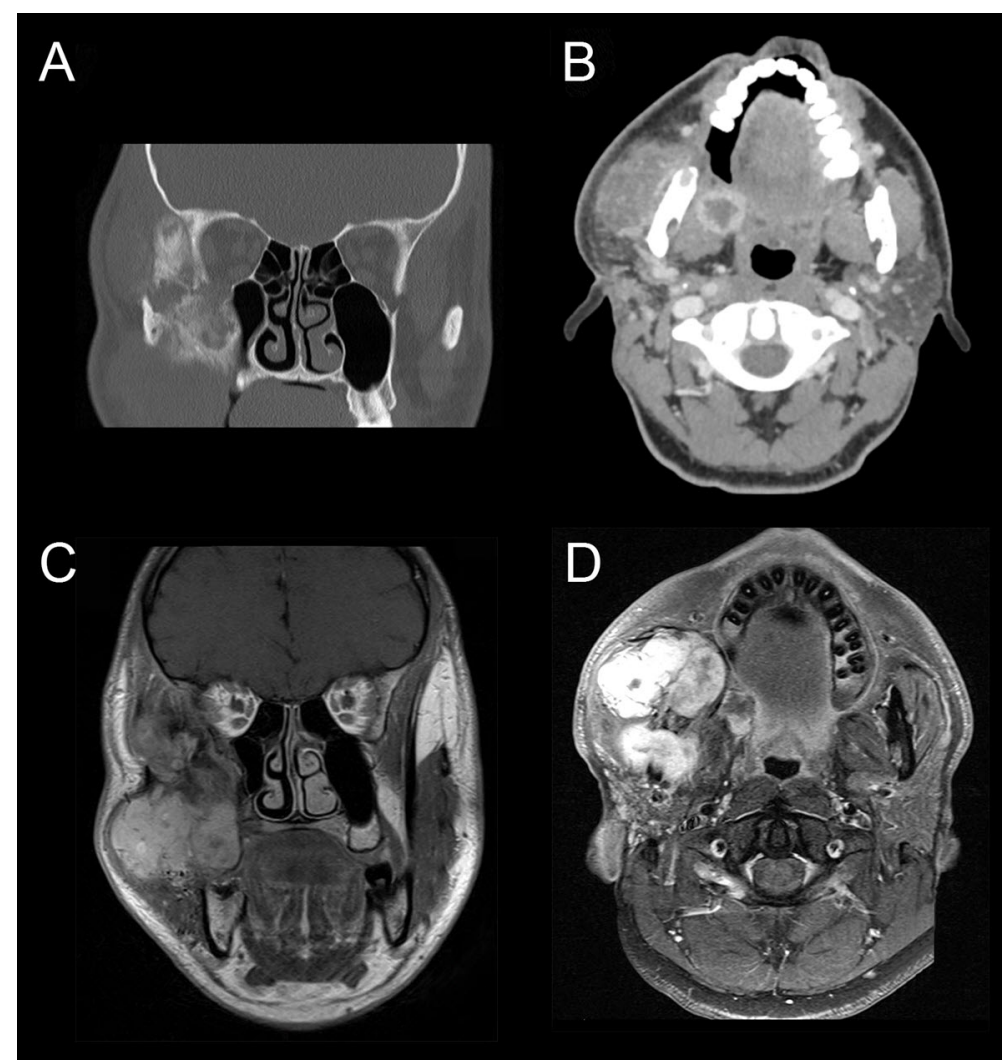

Fig. (1). A-D. Preoperative CT-scan and MRI. CT-scan (panels A and B) and MRI (C and D); coronal and axial sections of the midface with osteosarcoma.

Microscopic study of the biopsied specimen from posterior maxilla revealed a non-epithelial malignant tumor associated with neoplastic bone and osteoid. The patient then underwent surgical removal of the tumor by extraoral incision. The zygomatic arch was removed temporarily to gain access to deeper parts of the midface (Figs. 2A-C). Unfortunately, it was difficult to achieve a clear margin due to tumor expansion within the inferior orbit and deep parts of fossa pterygopalatina. 

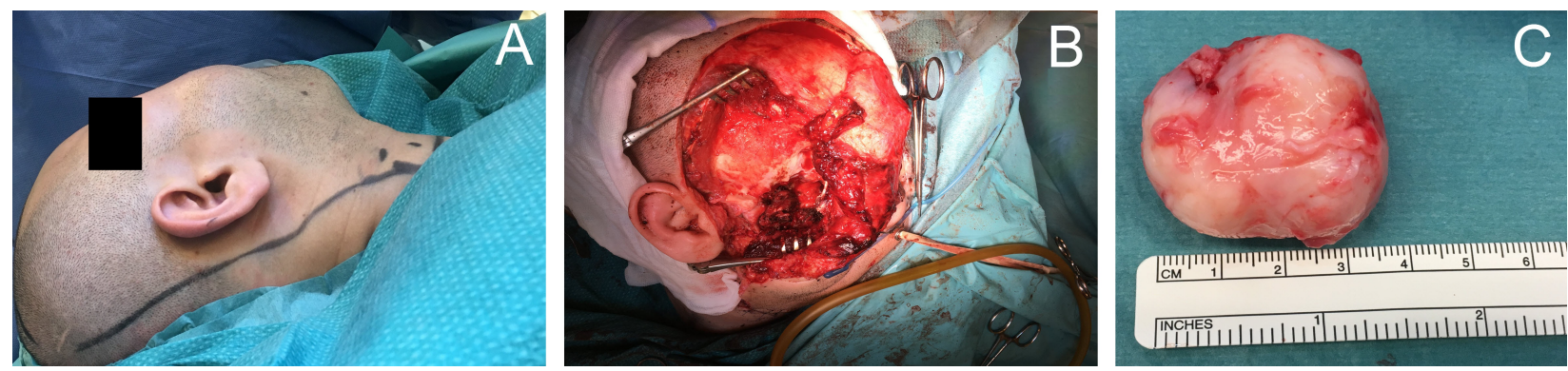

Fig. (2). A. Clinical photo showing swelling of the midface. B. Surgical resection of osteosarcoma by external flap and removal of zygomatic complex. C. Tumor removed at the right posterior maxilla.

Macroscopic appearance of the tumor samples was characterized by two components: well-demarcated sarcomatous solid lesion (Fig. 3A) and exophytic bone fragments (Fig. 3B).
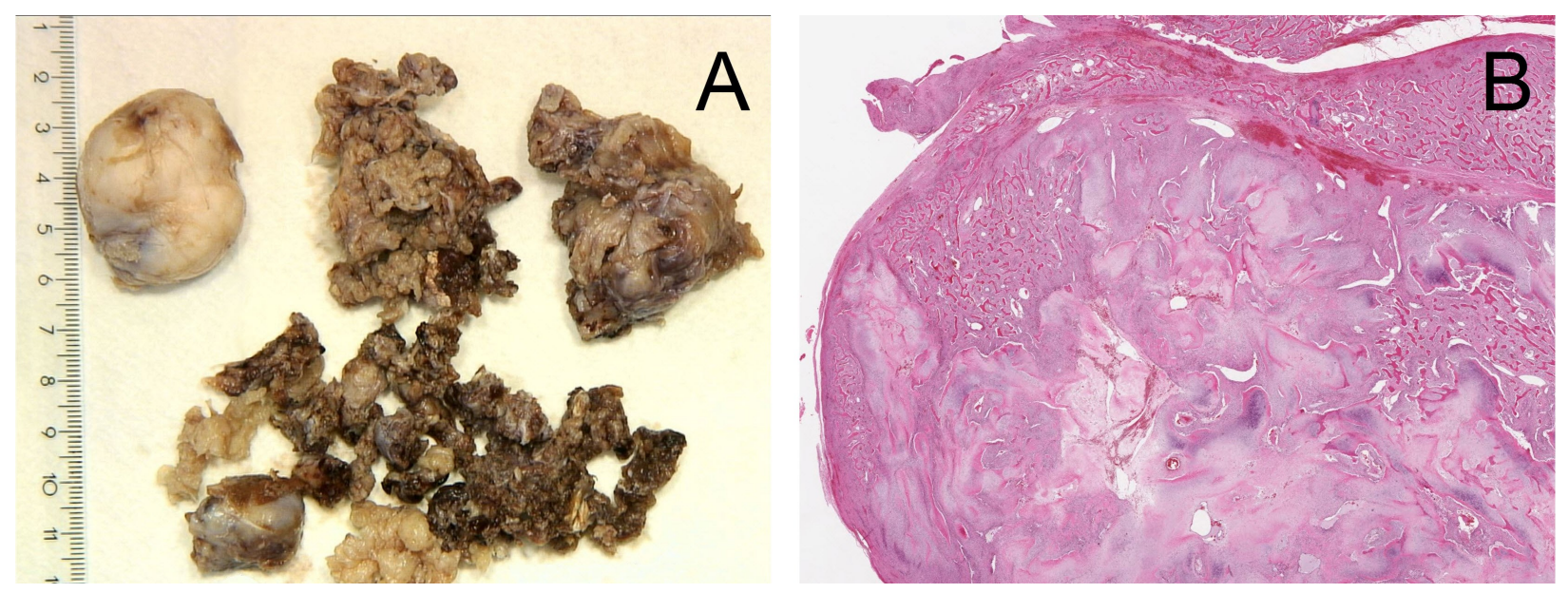

Fig. (3). A. Macroscopic view of sarcomatous solid lesion. B. A lupe view of the histological section of the exophytic bone growth.

Final histological analysis showed malignant tumor with heterogeneous morphology and three distinctly different components: (1) a fibrous component with moderate cellularity and atypical cells (Fig. 4A); (2) a component with varying enchondral ossification with cartilaginous tissue (Fig. 4B). The chondrocytes were irregularly arranged and showed some pleomorphism and binucleation. Low-power magnification showing the typical, well-differentiated irregular woven boney trabeculae, focally arranged in parallel arrays in a background of spindle cell stroma (streamer pattern) (Fig. 4C); (3) a high-grade malignant component with pleomorphic spindle cell sarcomatous/malignant fibrous tissue that produced malignant woven bone with growth infiltratively into the bone trabeculae (Fig. 4D). Furthermore, the number of mitotic figures revealed 12 per 10 High-Power Fields (HPF). The presence of high-grade component warranted the diagnosis of dedifferentiated parosteal osteosarcoma.

Immunohistochemical analysis was performed on $4 \mathrm{~mm}$ thick formalin-fixed, paraffin-embedded tissue sections and the evaluation was performed on stromal spindle cells. The tumor cells were immunohistochemically positive for MDM2 and CDK4 (Figs. 4E \& F).

The patient was subjected to further chemotherapy treatment due to lack of clear margin and residual tumor. Four courses of chemotherapy regimens comprising cisplatin/doxorubicin in combination with iphosphamide/etoposide were administered. The patient underwent MRI examination one month after the final course of chemotherapy. MRI showed residual tumor at the posterior maxilla, extending to space around the condyle (Figs. 5A \& B). Two months later, the patient received palliative radiotherapy. His symptoms improved during the 6 months after radiotherapy, with only a slight swelling at the right side of his face. However, by the time of the 2.5 -year follow-up, the patient had already died. 

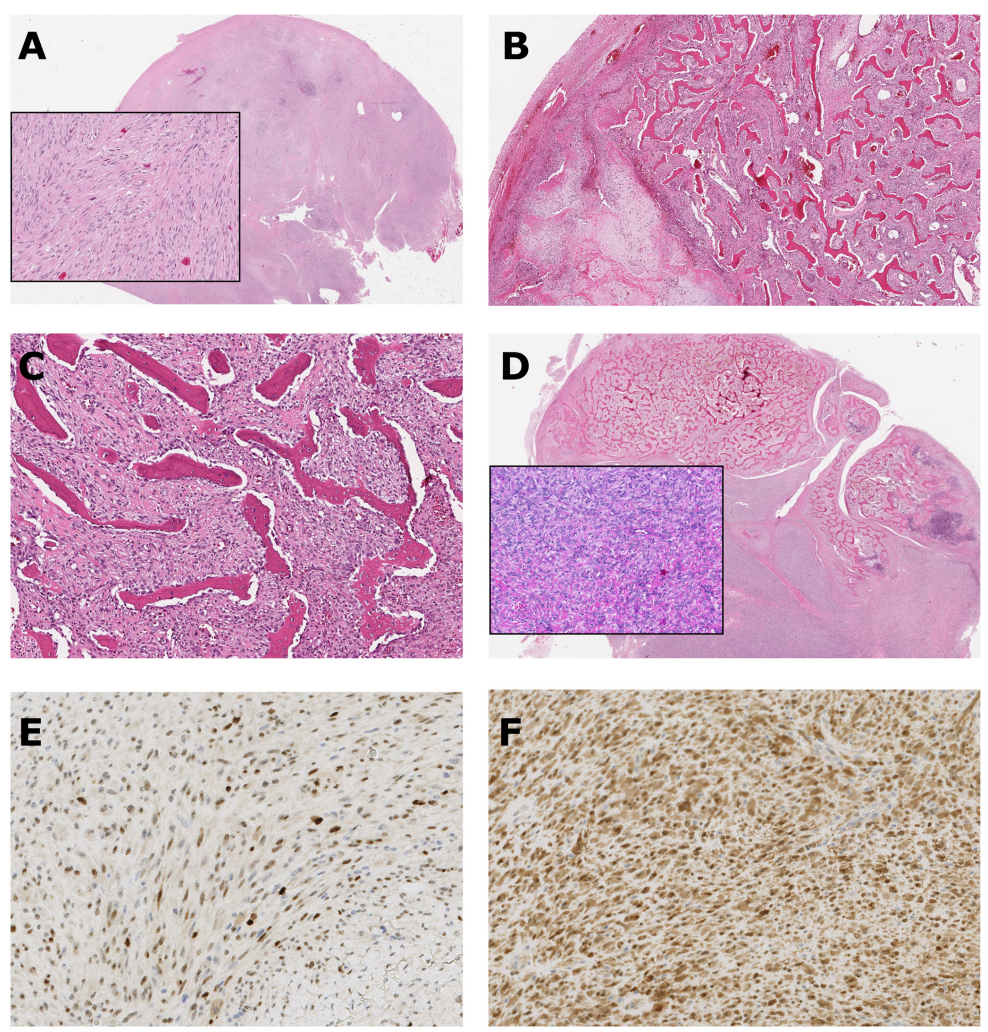

Fig. (4). Histological and immunohistochemical images. A. Histological image of fibrous component with moderate cellularity and atypical cells. B. Histological image showing enchondral ossification with cartilaginous tissue. C. Histological image of typical, well-differentiated irregular-woven boney trabeculae, focally arranged in parallel arrays in a background of spindle cell stroma (streamer pattern). D. Histological image of high-grade component with spindle cell sarcomatous fibrous tissue with mitotic nuclei. The sarcomatous tissue has grown infiltratively into the bone trabeculae. E and F. Immunohistochemical staining for MDM2 (E) and CDK4 (F) showing positive nuclear staining.

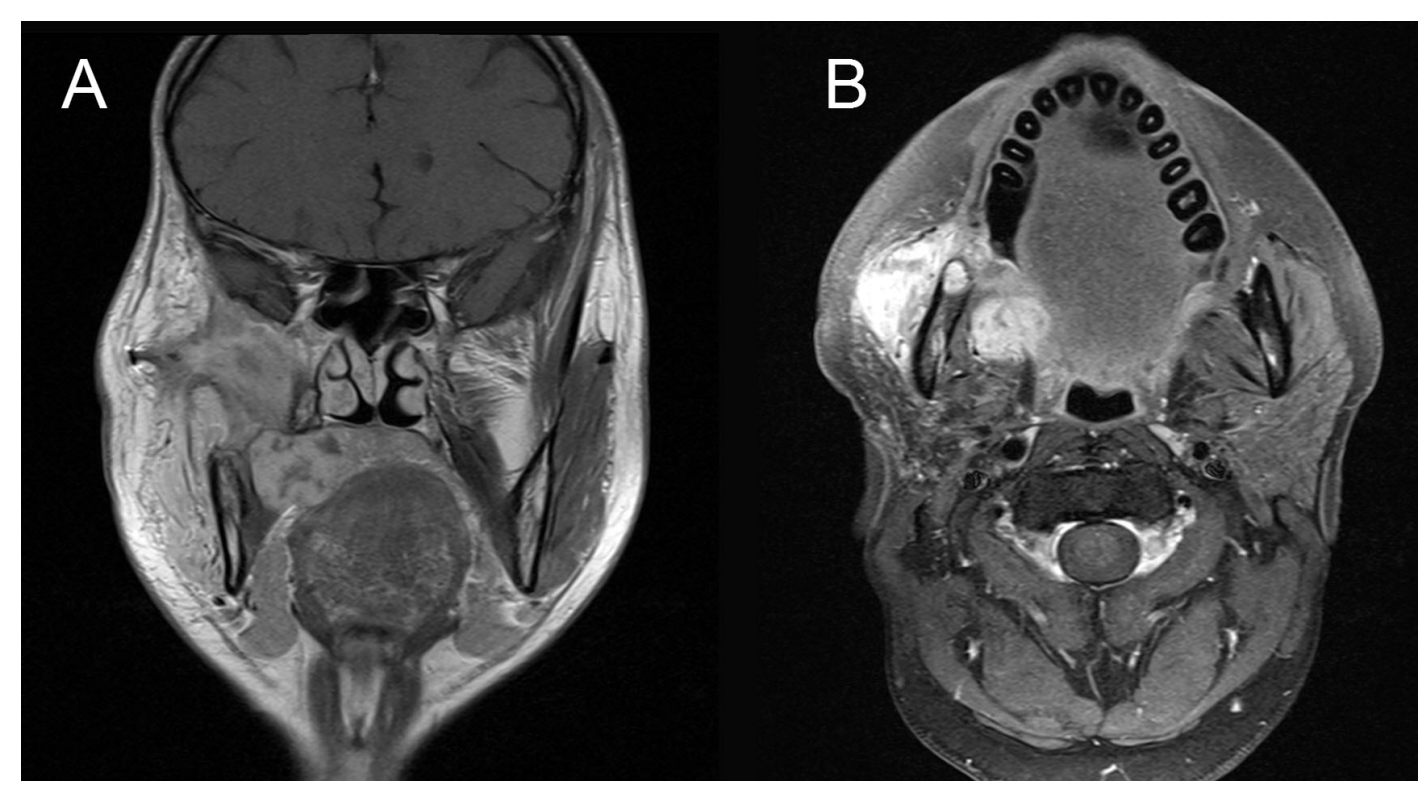

Fig. (5). A and B. MRI, one month after chemotherapy, showed residual tumor at the posterior maxilla, extending to space around the condyle. 


\section{RESULTS OF LITERATURE REVIEW}

The initial search of Medline yielded a total of 75 articles. After a second screening, 19 articles met the inclusion criteria of the study. The remaining 56 articles were excluded because they did not address the key areas listed above. Of the 18 articles selected, there were two case series and 16 case reports. The demographic data on age, site, presenting features, management, follow-up, and malignant transformation are presented in Table $\mathbf{1}$.

Table 1. Cases of parosteal osteosarcoma of the jaw. Demographic data, clinical outcome, and treatment outcome.

\begin{tabular}{|c|c|c|c|c|c|c|c|c|c|c|}
\hline Studies & $\begin{array}{l}\text { Number } \\
\text { of Cases }\end{array}$ & Sites & $\begin{array}{c}\text { Age } \\
\text { (years) }\end{array}$ & Sex & $\begin{array}{l}\text { Stage } \\
\text { AJCC }\end{array}$ & Symptoms & $\begin{array}{c}\text { Distance } \\
\text { Metastasis }\end{array}$ & $\begin{array}{c}\text { Follow-up } \\
\text { Time (Years) }\end{array}$ & Treatment & Outcome \\
\hline \multicolumn{11}{|c|}{ Without Primary Diagnosis } \\
\hline \multirow[t]{2}{*}{ Roca et al. 1970} & \multirow[t]{2}{*}{2} & $1 \mathrm{MN}$ & 63 & $\mathrm{M}$ & IIB & Painless swelling & No & 6 years & $\mathrm{S}$ & LR \\
\hline & & $1 \mathrm{MX}$ & 17 & $\mathrm{~F}$ & IA & Painless swelling & No & 9 years & $\mathrm{S}$ & $\mathrm{DF}$ \\
\hline $\begin{array}{c}\text { Solomon et al. } \\
1975\end{array}$ & 1 & $\mathrm{MN}$ & 38 & $\mathrm{M}$ & IIB & Painless swelling & No & 6 months & $S$ & DF \\
\hline $\begin{array}{c}\text { Newland et al. } \\
1977\end{array}$ & 1 & MX & 25 & M & IIB & Painless swelling & No & Unknown & $S$ & $\mathrm{DF}$ \\
\hline \multirow[t]{2}{*}{ Regezi et al. 1987} & \multirow[t]{2}{*}{2} & MX & 13 & $\mathrm{~F}$ & & Painless swelling & No & 5 years & $\mathrm{S}$ & DF \\
\hline & & MX & 68 & $\mathrm{M}$ & & Painless swelling & No & 5 years & $\mathrm{S}$ & LR \\
\hline Strunk et al. 1990 & 1 & $\begin{array}{c}\text { Mastoid } \\
\text { bone }\end{array}$ & 27 & $\mathrm{M}$ & IIB & $\begin{array}{l}\text { Painless swelling, } \\
\text { drainage from ear }\end{array}$ & No & 14 months & $\mathrm{S}$ & $\mathrm{DF}$ \\
\hline Oda et al. 1996 & 1 & MX & 39 & $\mathrm{M}$ & IA & Swelling and pain & No & 21 months & $\mathrm{S}$ & DF \\
\hline Bianchi et al. 1997 & 1 & MX & 47 & $\mathrm{~F}$ & IA & Painless swelling & No & 6 years & $S$ & DF \\
\hline $\begin{array}{c}\text { Donaldson et al. } \\
2004\end{array}$ & 1 & MN & 8 & $M$ & IA & $\begin{array}{c}\text { Swelling and nasal } \\
\text { congestion }\end{array}$ & No & 3.5 years & S & DF \\
\hline Isokane et al. 2005 & 1 & MX & 17 & $\mathrm{~F}$ & III & Painless swelling & Pulmonary & Unknown & $\mathrm{CT}$ & Died \\
\hline Hewitt et al. 2007 & 1 & MX & 32 & $\mathrm{M}$ & IA & Painless swelling & No & 3 years & $\mathrm{S}$ & $\mathrm{DF}$ \\
\hline $\begin{array}{c}\text { Chakravarti et al. } \\
2015\end{array}$ & 1 & $\mathrm{MN}$ & 35 & $\mathrm{~F}$ & IIB & Swelling and pain & No & 4 years & $\mathrm{S}$ & $\mathrm{DF}$ \\
\hline Simon et al. 2011 & 1 & $\mathrm{MN}$ & 54 & $\mathrm{~F}$ & IA & Painless swelling & No & 16 months & $S$ & $\mathrm{DF}$ \\
\hline Vaidya et al. 2011 & 1 & $\mathrm{MN}$ & 43 & $F$ & IIB & Swelling and pain & No & 1 year & $\mathrm{S}$ & DF \\
\hline Puranik et al. 2014 & 1 & MX & 22 & $\mathrm{~F}$ & IB & Painless swelling & No & 1.5 years & $\mathrm{S}$ & DF \\
\hline & & & & & With Pr & imary Diagnosis & & & & \\
\hline Huang et al. $2010^{*}$ & 1 & MX & 33 & $\mathrm{M}$ & IA & Painless swelling & No & 7 years & $\mathrm{S}, \mathrm{CT}$ & DF \\
\hline $\begin{array}{c}\text { Demicco et.al. } \\
2010\end{array}$ & 1 & $\mathrm{MN}$ & 66 & $\mathrm{~F}$ & IA & swelling & No & 57 months & $\mathrm{S}$ & $\mathrm{DF}$ \\
\hline Argon et al. $2015 *$ & 1 & $\mathrm{MN}$ & 26 & $\mathrm{~F}$ & IA & Painless swelling & No & Unknown & $S$ & DF \\
\hline Lee et al. $2015^{* *}$ & 1 & $\mathrm{MN}$ & 45 & $\mathrm{M}$ & IA & Swelling and pain & No & Unknown & $\mathrm{S}$ & DF \\
\hline $\begin{array}{c}\text { Abtahi et al. } 2018 \\
* * *\end{array}$ & 1 & MX & 20 & $M$ & IA & Swelling and pain & No & 6 months & $\mathrm{S}, \mathrm{CT}, \mathrm{RT}$ & Died \\
\hline Summary & 21 & $\begin{array}{c}8 \mathrm{MN} \\
11 \mathrm{MX} \\
1 \text { other }\end{array}$ & $\begin{array}{l}\text { Mean } \\
33.6\end{array}$ & \begin{tabular}{|c|}
$11 \mathrm{M}$ \\
$9 \mathrm{~F}$
\end{tabular} & - & - & $1 \mathrm{DM}$ & $\begin{array}{c}\text { Mean } \\
42\end{array}$ & - & - \\
\hline $\begin{array}{l}\text { AJCC, American Joi } \\
\text { LR, Local Recurrenc } \\
\text { * Fibrous dysplasia. } \\
\text { ** Cemento-ossifyin } \\
\text { *** Ossifying fibron }\end{array}$ & $\begin{array}{l}\text { nt Commit } \\
\text { e; DF, Dis } \\
\text { g fibroma. }\end{array}$ & $\begin{array}{l}\text { on Canc } \\
\text { se-free; D }\end{array}$ & F, Fen & e & $\begin{array}{l}\text { Male; N } \\
\text { stasis. }\end{array}$ & , Maxilla; $\mathrm{MN}, \mathrm{M}$ & & $\mathrm{y}$; CT, Chen & erapy; RT & diotherapy \\
\hline
\end{tabular}

\section{DISCUSSION}

Twenty cases of POSJ have been described in the literature [21, 22, 24 - 38]. Four cases represent the possible development of this tumor by transformation from a fibro-osseous neoplasm: two cases of fibrous dysplasia, one case of cemento-ossifying fibroma [21, 22, 37], and the case of OF in the present study.

The connection between fibro-osseous lesions and transformation to malignant tumors has been studied previously $[13,39,40]$. Histological differentiation of low-grade lesions from reactive processes or benign fibro-osseous lesions can be difficult. Immunohistochemistry (IHC) plays an important role in the differentiation between various types of osteosarcoma. Yoshida et al., demonstrated the usefulness of IHC markers such as Murine Double-Minute type 2 
(MDM2) and Cyclin-Dependent Kinase 4 (CDK4) in diagnosis and differentiation of low-grade osteosarcoma from benign histological mimics [41].

So far, about 100 cases of malignancy in Fibrous Dysplasia (FD) have been reported, where osteosarcoma is the most common, followed by fibrosarcoma and chondrosarcoma [40]. Sugiura et al., were the first to report (in a case report of one case) that osteosarcoma is derived from the spindle cells in FD, probably associated with a GNAS mutation [15]. We are now reporting a case with osteosarcoma in the same region as a previous OF. This finding might be of importance in the management of patients with OF, concerning their follow-up after surgery. A close follow-up of these patients might be important in order to identify malignant transformation. Further studies are needed to confirm this finding. Furthermore, in the case presented, the OF lesion was surgically removed with radical margins. It might therefore be of importance to investigate further whether malignant transformation is spontaneous or whether it occurs as a result of surgery.

In this review the maxilla was more commonly affected in 11 cases, whereas the mandible was affected in nine cases. Most patients presented with painless, hard swellings in the affected area. This might delay diagnosis in the maxillary region, which may explain the poor prognosis. In this paper we have presented a rare case of occurrence of osteosarcoma with involvement of the posterior maxilla, orbit floor, and infra-temporal fossa in a 20-year-old man. In the literature, there have only been two previous cases of POSJ in the midface

$[42,43]$. One patient with midface POSJ (aged 17 years) died, and the other one (22 years old) was disease-free at follow-up.

The single most important factor for cure is aggressive surgical resection of POSJ. However, in the maxillofacial region clear margins may be difficult to achieve, especially in the midface. The role of chemotherapy is still unknown, just as it is in the treatment of conventional osteosarcoma [44]. In a retrospective study by Latininen et al., 80 patients with POS were evaluated regarding the prognostic and therapeutic factors over a mean follow-up time of 11.2 years. Five-year and ten-year survival was $91.8 \%$ and $87.8 \%$, respectively. Local recurrence occurred in 14 patients (17.5\%); this was associated with large volume of the tumor. Distant metastases were uncommon and the use of chemotherapy had no effect on survival [44]. However, Nouri et al., have emphasized the importance of histological grade of malignancy in surface osteosarcomas, concerning treatment and prognosis. They suggested wide resection of low-grade lesions and a more aggressive surgical approach in high-grade lesions in combination with postoperative chemotherapy [45]. Previous studies show that high-grade components might develop de-novo from low grade POS in up to $43 \%$ of cases [46]. Development of high-grade components from low-grade tumor has yet not been studied in POSJ. In this study we present an unusual case of POSJ with high-grade component.

The metastatic rate for POSJ is generally lower than in locations other than the jaws [44]. In a case-series of 15 patients with well-differentiated OSJ no metastasis were reported at 2 year follow-up. Among these, one patient was diagnosed with POSJ [47]. In our study we present a review of 21 POSJ, 2 patients died and one had pulmonary metastasis (Table 1). POSJ has a 5-year survival rate of $91.8 \%$, however our patient died after 2.5 years of follow-up. This might be explained by the difficulty of achieving clear margins in the maxillary region, but also by the presence of high-grade component (Fig. 4D). Dedifferentiation of low-grade osteosarcomas into high-grade osteosarcomas has previously been found in 10-36\% of cases [48]. The dedifferentiation can be diagnosed with immunohistochemistry, and it has been found that finding co-expression of MDM2 and CDK4 in high-grade osteosarcomas has high sensitivity and specificity to detect high-grade osteosarcomas that have progressed from low-grade lesions [41]. However, highgrade surface osteosarcomas have not previously been found in the craniofacial region. Thus, to our knowledge we are presenting the first case of this nature.

\section{CONCLUSION}

We have presented an unusual case of POSJ of the midface in a patient with a previous diagnosis of OF in the same region. To our knowledge, there have been no previous reports of development of POSJ in OF. Furthermore, this is the first described case of high-grade surface osteosarcoma in the craniofacial region.

\section{ETHICS APPROVAL AND CONSENT TO PARTICIPATE}

Not applicable. 


\section{HUMAN AND ANIMAL RIGHTS}

Not applicable.

\section{CONSENT FOR PUBLICATION}

Informed consent was obtained from the patient prior to being enrolled in the study.

\section{CONFLICT OF INTEREST}

The authors declare no conflict of interest, financial or otherwise.

\section{ACKNOWLEDGEMENTS}

This study was supported by the Department of Oral and Maxillofacial Surgery, Linköping University Hospital, Sweden.

\section{REFERENCES}

[1] Sissons HA. The WHO classification of bone tumors. Recent Results Cancer Res 1976; (54): 104-8. [PMID: 1070715]

[2] Mirabello L, Troisi RJ, Savage SA. Osteosarcoma incidence and survival rates from 1973 to 2004: Data from the Surveillance, Epidemiology, and End Results Program. Cancer 2009; 115(7): 1531-43. [http://dx.doi.org/10.1002/cncr.24121] [PMID: 19197972]

[3] Padilla RJ, Murrah VA. The spectrum of gnathic osteosarcoma: Caveats for the clinician and the pathologist. Head Neck Pathol 2011; 5(1): 92-9. [http://dx.doi.org/10.1007/s12105-010-0218-y] [PMID: 21046296]

[4] Fernandes R, Nikitakis NG, Pazoki A, Ord RA. Osteogenic sarcoma of the jaw: A 10-year experience. J Oral Maxillofac Surg 2007; 65(7): 1286-91.

[http://dx.doi.org/10.1016/j.joms.2006.10.030] [PMID: 17577490]

[5] Huber GF, Dziegielewski P, Wayne Matthews T, Dort JC. Head and neck osteosarcoma in adults: The province of alberta experience over 26 years. J Otolaryngol Head Neck Surg 2008; 37(5): 738-43. [PMID: 19128686]

[6] Mendenhall WM, Fernandes R, Werning JW, Vaysberg M, Malyapa RS, Mendenhall NP. Head and neck osteosarcoma. Am J Otolaryngol 2011; 32(6): 597-600.

[http://dx.doi.org/10.1016/j.amjoto.2010.09.002] [PMID: 21093108]

[7] Unni KK, Dahlin DC. Osteosarcoma: Pathology and classification. Semin Roentgenol 1989; 24(3): $143-52$. [http://dx.doi.org/10.1016/0037-198X(89)90010-2] [PMID: 2772662]

[8] Wei Z, Xie Y, Xu J, et al. Radiation-induced sarcoma of head and neck: 50 years of experience at a single institution in an endemic area of nasopharyngeal carcinoma in China. Med Oncol 2012; 29(2): 670-6. [http://dx.doi.org/10.1007/s12032-011-9828-9] [PMID: 21259056]

[9] Karaüzüm SB, Hazar V, Açikbas I, Gelen T, Yessilipek MA, Lüleci G. Existence of acute lymphoblastic leukemia and osteosarcoma in a child. J Pediatr Hematol Oncol 2002; 24(7): 572-4. [http://dx.doi.org/10.1097/00043426-200210000-00017] [PMID: 12368699]

[10] Gon S, Majumdar B, Bhattacharyya A, Bhattacharya R. Fibrous dysplasia: Rapid malignant transformation into osteogenic sarcoma-A rare occurance. J Pathol Nepal 2012; 2: 335-7. [http://dx.doi.org/10.3126/jpn.v2i4.6891]

[11] Kaushik S, Smoker WR, Frable WJ. Malignant transformation of fibrous dysplasia into chondroblastic osteosarcoma. Skeletal Radiol 2002; 31(2): 103-6.

[http://dx.doi.org/10.1007/s002560100436] [PMID: 11828332]

[12] Ebata K, Usami T, Tohnai I, Kaneda T. Chondrosarcoma and osteosarcoma arising in polyostotic fibrous dysplasia. J Oral Maxillofac Surg 1992; 50(7): 761-4. [http://dx.doi.org/10.1016/0278-2391(92)90116-H] [PMID: 1608009]

[13] Ruggieri P, Sim FH, Bond JR, Unni KK. Malignancies in fibrous dysplasia. Cancer 1994; 73(5): 1411-24. [http://dx.doi.org/10.1002/1097-0142(19940301)73:5<1411::AID-CNCR2820730516>3.0.CO;2-T] [PMID: 8111708]

[14] Kim GT, Lee JK, Choi BJ, Kim J, Han SH, Kwon YD. Malignant transformation of monostotic fibrous dysplasia in the mandible. J Craniofac Surg 2010; 21(2): 601-3. [http://dx.doi.org/10.1097/SCS.0b013e3181d08ca8] [PMID: 20489463]

[15] Salinas-Souza C, De Andrea C, Bihl M, et al. GNAS mutations are not detected in parosteal and low-grade central osteosarcomas. Mod Pathol 2015; 28(10): 1336-42. 
[http://dx.doi.org/10.1038/modpathol.2015.91] [PMID: 26248895]

[16] Chen CY, Zhang HZ, Jiang ZM, Zhou J, Chen J, Liu L. Value of MDM2, CDK4 and SATB2 immunohistochemistry in histologic diagnosis of low-grade osteosarcoma. Zhonghua Bing Li Xue Za Zhi 2016; 45(6): 387-92. [PMID: 27256046]

[17] Chang CC, Hung HY, Chang JY, et al. Central ossifying fibroma: A clinicopathologic study of 28 cases. J Formos Med Assoc 2008; 107(4): $288-94$.

[http://dx.doi.org/10.1016/S0929-6646(08)60089-3] [PMID: 18445542]

[18] Triantafillidou K, Venetis G, Karakinaris G, Iordanidis F. Ossifying fibroma of the jaws: A clinical study of 14 cases and review of the literature. Oral Surg Oral Med Oral Pathol Oral Radiol 2012; 114(2): 193-9. [http://dx.doi.org/10.1016/j.tripleo.2011.07.033] [PMID: 22776732]

[19] Eversole LR, Merrell PW, Strub D. Radiographic characteristics of central ossifying fibroma. Oral Surg Oral Med Oral Pathol 1985; 59(5): 522-7.

[http://dx.doi.org/10.1016/0030-4220(85)90096-9] [PMID: 3859811]

[20] Trijolet JP, Parmentier J, Sury F, Goga D, Mejean N, Laure B. Cemento-ossifying fibroma of the mandible. Eur Ann Otorhinolaryngol Head Neck Dis 2011; 128(1): 30-3. [http://dx.doi.org/10.1016/j.anorl.2010.06.005] [PMID: 20846921]

[21] Huang TC, Monsour PA, Chahoud CD. Parosteal osteosarcoma: Report of a case and review of the literature. Aust Dent J 2010; 55(1): 86-91. [http://dx.doi.org/10.1111/j.1834-7819.2009.01175.x] [PMID: 20415917]

[22] Lee YB, Kim NK, Kim JY, Kim HJ. Low-grade osteosarcoma arising from cemento-ossifying fibroma: A case report. J Korean Assoc Oral Maxillofac Surg 2015; 41(1): 48-51. [http://dx.doi.org/10.5125/jkaoms.2015.41.1.48] [PMID: 25741469]

[23] Argon A, Doğanavşargıl B, Ünal Yıldırım F, Sezak M, Midilli R, Öztop F. Osteosarcomas of jaw: Experience of a single centre. J Plast Surg Hand Surg 2015; 49(1): 13-8. [http://dx.doi.org/10.3109/2000656X.2014.909364] [PMID: 24780088]

[24] Hoffman S, Jacoway JR, Krolls SO. Atlas of tumor pathology - Intraosseous and parosteal tumors of the jaws. Washington, DC: Armed Forces Institute of Pathology 1987; p. 242.

[25] Simon D, Dominic S, Varghese KG. Juxtacortical osteogenic sarcoma of the jaws: Case report and review of the literature. J Oral Maxillofac Surg 2011; 69(2): 527-31.

[http://dx.doi.org/10.1016/j.joms.2010.05.028] [PMID: 21094571]

[26] Solomon MP, Biernacki J, Slippen M, Rosen Y. Parosteal osteogenic sarcoma of the mandible, existence masked by diffuse periodontal inflammation. Arch Otolaryngol 1975; 101(12): 754-60. [http://dx.doi.org/10.1001/archotol.1975.00780410046011] [PMID: 1060441]

[27] Newland JR, Ayala AG. Parosteal osteosarcoma of the maxilla. Oral Surg Oral Med Oral Pathol 1977; 43(5): 727-34. [http://dx.doi.org/10.1016/0030-4220(77)90057-3] [PMID: 266153]

[28] Regezi JA, Zarbo RJ, McClatchey KD, Courtney RM, Crissman JD. Osteosarcomas and chondrosarcomas of the jaws: Immunohistochemical correlations. Oral Surg Oral Med Oral Pathol 1987; 64(3): 302-7. [http://dx.doi.org/10.1016/0030-4220(87)90009-0] [PMID: 2443891]

[29] Strunk CL, Williams RW. Parosteal osteosarcoma. Otolaryngol Head Neck Surg 1992; 106(2): 202-5. [PMID: 1738555]

[30] Oda D, Bavisotto LM, Schmidt RA, et al. Head and neck osteosarcoma at the University of Washington. Head Neck 1997; 19(6): 513-23. [http://dx.doi.org/10.1002/(SICI)1097-0347(199709)19:6<513:AID-HED9>3.0.CO;2-1] [PMID: 9278760]

[31] Bianchi SD, Boccardi A, Pomatto E, Valente G. Parosteal osteosarcoma of the maxilla. Dentomaxillofac Radiol 1997; 26(5): 312-4. [http://dx.doi.org/10.1038/sj.dmfr.4600262] [PMID: 9482005]

[32] Donaldson ME, Geist JR, Daley TD. Osteosarcoma of the jaws in children. Int J Paediatr Dent 2004; 14(1): 54-60. [http://dx.doi.org/10.1111/j.1365-263X.2004.00519.x] [PMID: 14706029]

[33] Isokane M, Sumida T, Okuhira T, Shintani S, Hamakawa H. Surface osteosarcoma: 2 case reports. Am J Otolaryngol 2006; 27(5): 349-52. [http://dx.doi.org/10.1016/j.amjoto.2005.11.019] [PMID: 16935183]

[34] Hewitt KM, Ellis G, Wiggins R, Bentz BG. Parosteal osteosarcoma: Case report and review of the literature. Head Neck 2008; 30(1): 122-6. [http://dx.doi.org/10.1002/hed.20658] [PMID: 17615569]

[35] Vaidya SB, Nadarajan S, Galinde JS, Bhardwaj AS. Juxtacortical osteosarcoma of mandible. Ann Maxillofac Surg 2011; 1(2): 172-5. [http://dx.doi.org/10.4103/2231-0746.92789] [PMID: 23483235]

[36] Puranik SR, Puranik RS, Ramdurg PK, Choudhary GR. Parosteal osteosarcoma: Report of a rare juxtacortical variant of osteosarcoma affecting the maxilla. J Oral Maxillofac Pathol 2014; 18(3): 432-6. [http://dx.doi.org/10.4103/0973-029X.151340] [PMID: 25949002]

[37] Chakravarthi PS, Kattimani VS, Prasad LK, Satish PR. Juxtacortical osteosarcoma of the mandible: Challenges in diagnosis and management. Natl J Maxillofac Surg 2015; 6(1): 127-31. 
[http://dx.doi.org/10.4103/0975-5950.168232] [PMID: 26668470]

[38] Sugiura Y, Kanda H, Motoi N, et al. Osteosarcoma arising in fibrous dysplasia, confirmed by mutational analysis of GNAS gene. Pathol Res Pract 2018; 214(2): 318-24.

[http://dx.doi.org/10.1016/j.prp.2017.10.018] [PMID: 29268950]

[39] Huvos AG, Woodard HQ, Cahan WG, et al. Postradiation osteogenic sarcoma of bone and soft tissues. A clinicopathologic study of 66 patients. Cancer 1985; 55(6): 1244-55.

[http://dx.doi.org/10.1002/1097-0142(19850315)55:6<1244::AID-CNCR2820550617>3.0.CO;2-1] [PMID: 3855683]

[40] Ogunlewe MO, Ajayi OF, Adeyemo WL, Ladeinde AL, James O. Osteogenic sarcoma of the jaw bones: A single institution experience over a 21-year period. Oral Surg Oral Med Oral Pathol Oral Radiol Endod 2006; 101(1): 76-81. [http://dx.doi.org/10.1016/j.tripleo.2005.03.035] [PMID: 16360611]

[41] Yoshida A, Ushiku T, Motoi T, et al. MDM2 and CDK4 immunohistochemical coexpression in high-grade osteosarcoma: Correlation with a dedifferentiated subtype. Am J Surg Pathol 2012; 36(3): 423-31. [http://dx.doi.org/10.1097/PAS.0b013e31824230d0] [PMID: 22301501]

[42] Miller SF. Imaging features of juxtacortical chondroma in children. Pediatr Radiol 2014; 44(1): 56-63. [http://dx.doi.org/10.1007/s00247-013-2770-6] [PMID: 23955368]

[43] Gholamrezanezhad A, Basques K, Kosmas C. Peering beneath the surface: juxtacortical tumors of bone (part II). Clin Imaging 2018; 50: $113-22$.

[http://dx.doi.org/10.1016/j.clinimag.2018.01.005] [PMID: 29353715]

[44] Laitinen M, Parry M, Albergo JI, et al. The prognostic and therapeutic factors which influence the oncological outcome of parosteal osteosarcoma. Bone Joint J 2015; 97-B(12): 1698-703. [http://dx.doi.org/10.1302/0301-620X.97B12.35749] [PMID: 26637687]

[45] Nouri H, Ben Maitigue M, Abid L, et al. Surface osteosarcoma: Clinical features and therapeutic implications. J Bone Oncol 2015; 4(4): $115-23$.

[http://dx.doi.org/10.1016/j.jbo.2015.07.002] [PMID: 26730360]

[46] Hang JF, Chen PC. Parosteal osteosarcoma. Arch Pathol Lab Med 2014; 138(5): 694-9. [http://dx.doi.org/10.5858/arpa.2013-0030-RS] [PMID: 24786129]

[47] Deshpande V, Nielsen GP, Kattapuram SV, Rosenberg AE. Well-differentiated osteosarcoma of the jaw bones: A clinicopathologic study of 15 cases. Am J Surg Pathol 2010; 11: 1647-55.

[48] Guérin M, Thariat J, Ouali M, et al. A new subtype of high-grade mandibular osteosarcoma with RASAL1/MDM2 amplification. Hum Pathol 2016; 50: 70-8.

[http://dx.doi.org/10.1016/j.humpath.2015.11.012] [PMID: 26997440]

(C) 2018 Abtahi and Ajan.

This is an open access article distributed under the terms of the Creative Commons Attribution 4.0 International Public License (CC-BY 4.0), a copy of which is available at: https://creativecommons.org/licenses/by/4.0/legalcode. This license permits unrestricted use, distribution, and reproduction in any medium, provided the original author and source are credited. 